\title{
Institutional violence in high-risk pregnancy in the light of pregnant women and nurses
}

\author{
Violência institucional na gravidez de alto risco à luz das gestantes e enfermeiras \\ Violencia institucional en embarazos de alto riesgo a la luz de mujeres embarazadas y enfermeras
}

Ana Paula Cavalcante Ramalho Brilhante' ORCID: 0000-0002-6677-6077

Maria Salete Bessa Jorge'

ORCID: 0000-0001-6461-3015

'Universidade Estadual do Ceará. Fortaleza, Ceará, Brazil.

How to cite this article:

Brilhante APCR, Jorge MSB. Institutional violence in high-risk pregnancy in the light of pregnant women and nurses. Rev Bras Enferm. 2020;73(5):e20180816. doi: http://dx.doi.org/10.1590/0034-7167-2018-0816

Corresponding author: Ana Paula Cavalcante Ramalho Brilhante E-mail:apcrbrilhante@gmail.com

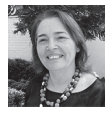

EDITOR IN CHIEF: Antonio José de Almeida Filho ASSOCIATE EDITOR: Cristina Parada

Submission: 10-30-2018

Approval: 09-26-2019

\begin{abstract}
Objective: to understand the perception of high-risk nurses and pregnant women about institutional violence in access to basic and specialized care networks in pregnancy. Method: a qualitative study developed from March to June 2017 in the city of Fortaleza, state of Ceará, with nurses and pregnant women at high risk. A semi-structured interview was used, analyzed by the thematic analysis technique. Three categories emerged: access of pregnant women to care networks; institutional violence in the perception of nurses; and institutional violence in the perception of pregnant women. Results: participants revealed deficiencies in knowledge about institutional violence. Nurses perceived this violence in the lack of resources and access, few recognized as a violation of rights. The pregnant women reported deficient access to care networks, medicines, tests, and did not perceive this difficulty as violence. Final considerations: institutional violence is present in high-risk pregnancy, nurses and pregnant women do not always perceive this violence as a violation of rights.

Descriptors: Violence; High-Risk Pregnancy; Prenatal Care; Comprehensive Health Care; Nursing.
\end{abstract}

\section{RESUMO}

Objetivo: compreender a percepção das enfermeiras e gestantes de alto risco sobre a violência institucional no acesso as redes de atenção básica e especializada na gestação. Método: estudo qualitativo, desenvolvido de março a junho de 2017, Fortaleza, Ceará, com enfermeiras e gestantes de alto risco. Utilizou-se entrevista semiestruturada, analisada pela técnica de análise temática, emergindo três categorias: acesso das gestantes às redes de atenção; violência institucional na percepção das enfermeiras e violência institucional na percepção das gestantes. Resultados: as participantes revelaram deficiência no conhecimento sobre violência institucional. As enfermeiras perceberam essa violência na insuficiência de recursos, no acesso, poucas reconheceram como violação de direito. As gestantes referiram deficiência no acesso às redes de atenção, medicamentos, exames, e não perceberam essa dificuldade como violência. Considerações finais: a violência institucional está presente na gestação de alto risco, enfermeiras e gestantes nem sempre percebem essa violência como violação de direitos.

Descritores: Violência; Gravidez de Alto Risco; Cuidado Pré-Natal; Atenção Integral à Saúde; Enfermagem.

\section{RESUMEN}

Objetivo: comprender la percepción de las enfermeras de alto riesgo y las mujeres embarazadas sobre la violencia institucional en el acceso a redes de atención básica y especializada durante el embarazo. Método: estudio cualitativo, desarrollado de marzo a junio de 2017, Fortaleza, Ceará, con enfermeras y mujeres embarazadas en alto riesgo. Se utilizó una entrevista semiestructurada, analizada por la técnica de análisis temático, surgiendo tres categorías: acceso de mujeres embarazadas a redes de atención; violencia institucional en la percepción de las enfermeras y violencia institucional en la percepción de las mujeres embarazada. Resultados: los participantes revelaron una falta de conocimiento sobre la violencia institucional. Las enfermeras percibieron esta violencia en la falta de recursos y acceso, pocos reconocidos como una violación de los derechos. Las mujeres embarazadas informaron un acceso deficiente a las redes de atención, medicamentos, pruebas y no percibieron esta dificultad como violencia. Consideraciones finales: La violencia institucional está presente en los embarazos de alto riesgo, las enfermeras y las mujeres embarazadas no siempre perciben esta violencia como una violación de los derechos. Descriptores: Violencia; Embarazo de Alto Riesgo; Cuidado Prenatal; Atención Integral de Salud; Enfermería. 


\section{INTRODUCTION}

Pregnancy is considered a natural physiological event that occurs uneventfully. However, in $20 \%$ of cases there is a likelihood of unfavorable evolution for both the fetus and the mother ${ }^{(1)}$, thus configuring a high-risk pregnancy, defined by a wide range of clinical, obstetric and/or social conditions that can lead to complications in pregnancy ${ }^{(1-3)}$.

These risks are mostly related to pre-existing illnesses or complications of pregnancy due to organic, biological, chemical and occupational causes, as well as to unfavorable social and demographic conditions ${ }^{(4-5)}$. Therefore, pregnant women who are in this condition need to be followed up by the Primary Care (PC) and Specialized Care (SC) networks and the nonguarantee of this care configures institutional violence from the violation of rights.

Institutional violence is exerted on/by public services, by action or omission. It may include from the broadest dimension of lack of access to poor quality services; pilgrimages for various services in search of care and long waits; effective and resolute assistance; failure to respect the right to non-discrimination; the service performed mechanically, without bond, affection and respect for the person who receives it; unethical practices against their clients/patients, therefore, in violation of health rights ${ }^{(6-7)}$.

In institutional violence, the presence of symbolic and structural violence is observed. In the case of this study, the violation of the rights of high-risk pregnant women may be related mainly to inequality and social exclusion. Thus, there is a denial to certain groups of the possibility of equal opportunities, including access to public policies such as health.

Among the elements that constitute the different forms of institutional violence in high-risk pregnancies, this article will be guided by symbolic violence and the structural violence present in the daily routine of health services, in one of its modalities, omission violence. This form of violence consists of the negligence and neglect experienced by high-risk pregnant women, when there is poor access in its different dimensions.

The relevance of the study on this theme is justified by the importance of giving greater visibility to situations experienced by women in high-risk pregnancy in Health Care Networks in the city of Fortaleza. Also, due to the lack of studies related to the institutional violence experienced by high-risk pregnant women in accessing $P C$ to $S C$.

This article discusses part of the results of the first author's doctoral dissertation entitled "Violência institucional às mulheres com gestação de risco: desafios para o acesso e o cuidado da Atenção Básica à Atenção Especializada". Given the above, the following guiding question is delimited: what is the perception of nurses and high-risk pregnant women regarding institutional violence in accessing the networks of PC and SC during pregnancy?

\section{OBJECTIVE}

To understand the perception of high-risk nurses and pregnant women about institutional violence in access to basic and specialized care networks in pregnancy.

\section{METHODS}

\section{Ethical aspects}

The research began after the project was approved by the Research Ethics Committee of Universidade Estadual do Ceará (UECE). The ethical and legal components are present in all phases of the research, in accordance with Resolution 466/12 of the Brazilian National Health Board (Conselho Nacional de Saúde). The representation of the names of the subjects was expressed by the acronym N (Nurse) and PW (Pregnant Woman), followed by number, according to the chronological order of the interview, ensuring confidentiality and anonymity.

Participants signed the Informed Consent Form (ICF), making it conditional on their participation, ensuring anonymity and confidentiality of information, confirmed by the use of a code for Nurses (N) and Pregnant Women (PW).

\section{Theoretical framework}

The core concepts of this study are based on the ideas of access presented by Assisi and Jesus ${ }^{(8)}$. They are based on Giovanella and Fleury ${ }^{(9)}$, who propose a model of analysis of access to services, seeking a multidimensional understanding of the problem, taking into account social and political aspects from Pierre Bourdieu's symbolic violence ${ }^{(10)}$, about Human Rights. This occurs from the sociological proposal regarding emancipation, denaturalization of the mechanisms of symbolic violence and structural violence according to Minayo ${ }^{(11)}$.

The theoretical assumptions sought in Bourdieu provided a better understanding of concealment or dissimulation by conquering the complicity of the dominated, that is, the recipients of symbolic violence ${ }^{(10-12)}$. In this way, the dominated, although angry, cannot, in isolation, oppose this domination, leaving it to accept it as natural ${ }^{(13)}$.

Thus, Bourdieu brings the proposal of emancipation, denaturalization and de-invisibility of situations experienced by high-risk pregnant women, when they are subjected to state domination, without realizing the violation of health rights. In this way, the dominated apply categories constructed from the dominant's point of view to the relations of domination, thus making them seen as natural $[. . .]^{(13)}$. Therefore, this kind of imposed, silent, silenced, naturalized and socially accepted violence often becomes invisible to the dominant and dominated relations of force and hierarchy.

In structural violence, it was based on Minayo ${ }^{(11)}$. He states that this type of "violence is generated by organized and institutionalized structures, naturalized and hidden in social structures, which is expressed in injustice and exploitation and which leads to the oppression of individuals". At certain times, certain interests of the exploited classes are satisfied with the intention of making them believe they are achieving their rights ${ }^{(11)}$.

Thus, the population is kept alienated to the institutional violence present in health services, which is subjected daily from the violation of the basic rights in the deficiency of meeting their needs. 


\section{Type of study}

It is a study based on the qualitative approach, in which it works with the universe of meanings, motives, aspirations, beliefs, values and attitudes. It corresponds to a deeper space of relationships, processes and phenomena that cannot be reduced to the operationalization of variables ${ }^{(14)}$. This type of study was chosen, as it made possible to apprehend and reveal the processes of subjectivation inherent to the theme studied.

\section{Study setting, population and period}

Fortaleza is divided administratively into six regional secretariats, and has five reference units for high-risk pregnancy, two from the municipal network, two state and one federal. The study was carried out in the PC and SC networks, i.e., in six Basic Health Units - BHU (one health unit per regional) and two specialized referral services for high-risk pregnancy (secondary and tertiary care) in the city. from Fortaleza, state of Ceará. Eight high-risk pregnant women and eight nurses participated in the research. Of these, six were from the PC network and two from the SC, totaling 16 interviews.

Inclusion criteria were nurses with employment relationship, linked to a Family Health Strategy (FHS) team and following up high-risk pregnant women. In SC, those who received high-risk pregnant women, when referred by the FHS, and who agreed to participate in the study, a necessary situation for both care networks.

As for the high-risk pregnant woman, she had to be referred by the FHS, had at least one appointment at the SC, lived in Fortaleza, had no cognitive impairment or any complication that prevented communication and agreed to participate in the study.

The interviews took place between March to June 2017, in a reserved place in health facilities, after contact with local management and prior appointment with nurses, during their working hours. Regarding the pregnant women, the interviews took place during the appointment at the specialized care reference unit. The average time for each interview was an average of forty minutes, were recorded, transcribed in full and coded.

\section{Collection and organization of data}

The semi-structured interview was used as a collection technique, with guiding questions that fostered discourse on the perception of nurses and pregnant women about institutional violence in high-risk prenatal care. This type of interview allows the interviewee the possibility to discuss the proposed theme without being attached to the question formulated and without answers or conditions prefixed by the researcher ${ }^{(15)}$.

The interview was guided by a script containing seven questions for pregnant women. It had themes such as characterization of participants, institutional violence, high-risk prenatal care from PC to SC, access and bonding with professionals from both care networks. Regarding nurses, eight questions were addressed, and in addition to the retro-mentioned issues, the facilities and difficulties in serving high-risk pregnant women, continuing education and the city's care model were added.

\section{Data analysis}

The analytical trajectory of the empirical material was based on content analysis, more specifically the thematic analysis technique. It, for Minayo ${ }^{(15)}$, "consists in discovering the nuclei of meaning that makes up a communication whose presence or frequency means something to the analytical objective aimed at" (p. 209). This technique consists of the following steps: pre-analysis, material exploration, treatment of the results obtained, inference and interpretation. In the pre-analysis, readings and rereading of the material were performed and the initial organization of the speeches aiming to obtain an overview of what was said by the participants and to understand the particularities. The analysis considered explicit and implicit discourses. Material exploration allowed us to grasp the relevance between the discourses of each participant, classify the central ideas and organize them into categories, aggregated by similarities. The stage of treatment of the results/inference/interpretation consisted in the elaboration of an interpretative synthesis of the three categories that emerged: 1) access of pregnant women to care networks; 2) institutional violence in the perception of nurses; 3 ) institutional violence in the perception of pregnant women.

\section{RESULTS}

Regarding the sociodemographic characterization of the eight pregnant women participating in the study, they had an average age of 34 years, ranging from 20-35 years. As for education, only two had not completed high school. Regarding the nurses, they were mostly female (7), had an average age of 35 years, all referred to one or more specialization, and one had the title of master. Following, the thematic categories that emerged from the speeches of the study participants:

\section{Access of high-risk pregnant women to primary and spe- cialized care networks}

In the city of the study, access to SC occurs after scheduling at the Customer Support Center (CSC). This occurs from the vacancies offered by the municipal regulation system, however, in the absence of the vacancy, the pregnant woman returns to the unit in search of this schedule. In this situation, the unit's coordination contacts the women's health technician of the regional health for referrals to the regional regulation and/or the central level, as follows:

[...] then, with this referral, the pregnant woman leads to the CSC [reception]. If there is no vacancy in the queue, I take the case to the unit coordinator, so that she can contact the woman's health officer in the region to expedite this appointment. It is often difficult, the pregnant woman returns to the unit several times in search of the schedule, because she never left scheduled, at least never seen. (N6)

Despite the existence of the regulatory system, it is still common to have informal flows, the use of different strategies, instituting movements performed mainly by nurses and pregnant women to access the SC. 
[...] in theory, we even know this flow, but we don't see it happening in practice. The issue of access to specialized appointment is still a major difficulty, although it is said in meetings that it will improve, there is a major obstacle in this issue, a situation that has consequences for women and children. (N3)

[...] whenever I serve a high-risk pregnant woman I get worried, because I know the difficulty. I refer to the doctor of my team to make the reference, but I know it is not easy, I keep calling to try the place for different places. (N1).

[...] it has been a while since I was referred by the health center doctor because my prenatal care was at risk, but only now near the end of my pregnancy did I get it. I think I spent more than two months waiting ... I only got it because I came here to have an ultrasound and I talked to the doctor here, so he could, if it wasn't that, I don't even know... (PW8)

[...] it was taking too long to get to the hospital, my pregnancy is at risk, I often went to the unit and kept waiting in line, so I went straight to the hospital and managed to make an appointment after I spoke of my case. I didn't go back to the health center. (PW3)

From the speeches of nurses of the two care networks, it was noticed that the reference to the specialized service for high-risk pregnant women still consists of challenges to be faced by the city, as the regulatory systems are still deficient.

[...] we carry out the referral in the first appointment to the reference unit with referral formalized by the electronic medical record. The pregnant woman is formally communicated, and oriented so that she takes her hands to the regional. Then, by telephone, the data of this pregnant woman are passed to the regional, in order to expedite the appointment. (N4)

[...] we see this a lot in prenatal care, last week, I caught several pregnant women who arrived with 38 weeks for screening, which only has vacancy next month, she will give birth and will not go through prenatal because of this pilgrimage...it takes too long to get here. (N7)

Therefore, it is possible to perceive the borderline situations faced by pregnant women and health professionals, especially nurses, since many pregnant women resort to this professional when they need it. It was noticed some BHU without scheduling the return of the pregnant woman after the appointment, contributing to the non-responsibility of care, according to the interviewees' speech:

[...] it took a long time to make an appointment at the hospital, and when she left she went away from home, and in the health unit I stayed for two months without appointment, they did not schedule my return. I had to go to the unit several times, because there is never a vacancy, neither for the doctor nor for the nurse, lack of medicines, exams, never had an ultrasound for the health center. (PW5)

[...] we used to schedule the return, our schedule is open monthly. Many times what happens, the schedule is not open, you can not schedule, even when the professional has made available the schedule well before...so the pregnant woman is going several times to schedule. (N1)

\section{Institutional violence in the perception of nurses}

Institutional violence was presented by the nurses interviewed in different ways, even as a new theme, revealing deficiency in the discussion about this form of violence, either in health services and/or in the training processes.

[...] this discussion is new to me, I have taken several courses on violence against women, but this issue has never been addressed. Violence against women is more discussed in relation to the Maria da Penha Law [Brazil's Federal Law 11340, also known as Lei Maria da Penha [Maria da Penha Law targets gender based violence in Brazil, with the specific aim of reducing domestic violence in the country] and childbirth at delivery, but not in this type. (N5)

Progressively, as the interview deepened, nurses' perceptions gained expression, visibility and non-naturalization. Some elaborated a broader conception of institutional violence, relating this form of violence to the violation of health rights, in its non-guarantee according to the country's Federal Constitution.

[...] / think this type of violence starts when the pregnant woman's basic needs, such as her exams, are not met, as we have even experienced routine exams, as well as the absence of iron, folic acid. The State does not fulfill its role. (N2)

[...] in our experience in health facilities, we do not have this organized network, we do not give the guarantee that this pregnant woman will have her prenatal complete, with all appointments, guaranteed exams, ultrasounds. Currently not guaranteed, even being high risk may not meet your needs. (N6)

Most of the interviewees perceive the presence of institutional violence in pregnancy only at the time of delivery, either in the form of treatment and/or pilgrimage, although they revealed different situations experienced by high-risk prenatal pregnant women that configure institutional violence, not always. perceive as such. Therefore, many situations present in high-risk prenatal care are not understood as violation of rights.

[...] for me, it is that woman who is in the maternity, who listens to jokes, who does not want to have normal childbirth, but has to have normal or the opposite. It is also present often at the time of childbirth as it seeks out various hospitals in search of service. (N8)

For those who reported that this form of violence is related to the violation of the right to health, revealed that little is discussed about this theme. For nurses, this type of violence also occurs against the health professional. This occurs when they do not have adequate working conditions to meet the pregnant woman, such as lack of privacy at the time of care, basic material resources, vacancies to ensure their returns, as shown below:

[....] the lack of working conditions is a form of institutional violence for pregnant women and professionals. We have a sonar for eight teams, often the balance is broken, anyway. There are many incomplete teams, no doctor, no health workers, all of which make it difficult and provoke different forms of violence, including institutional. (N4) 
[...] there is no privacy for the care of pregnant women, the unit is small for the number of teams, the professional next door listens to everything. There is prioritization of spontaneous demand, this is an institutional violence for pregnant women and professionals, hinders their monitoring even in family health, does not have enough vacancies. (N6)

These situations were revealed by some of the interviewees, as it is common the deficiency of structure, especially of material and human resources in PC and SC, impairing the quality of care to pregnant women, especially the high risk. The presence of incomplete teams and the deficiency of Community Health Agents (CHA) were present at the time of the study in the health regions, as well as the existence of differences in the organization of the work process.

The following speeches portray that there have been instituting movements by nurses, given the difficulty of referring pregnant women to specialized appointment. For the interviewees, different strategies and flows are used in search of access to specialized services, whether formal or informal. This situation leads to violation of rights, leading to institutional violence, although not explicitly.

[...] when the pregnant woman cannot schedule the appointment, we get in touch with the coordination of the technical area of women's health, regional regulation, with the tertiary hospital, even the SUS friend. It's often hard, we can't. (N3)

[...] / am worried when serving a risky pregnant woman, because lam soon remembering the difficulty in getting a vacancy in specialized care, yet knowing that will go to the regulatory system, I use various strategies informally. (N1)

\section{Institutional violence in the perception of pregnant women}

Institutional violence is poorly viewed by pregnant women. They still do not understand what is the right to health, as many of the pregnant women interviewed revealed difficulties experienced in pregnancy regarding access in their different dimensions, including the SC, medicines and/or examinations. However, many of them do not recognize these difficulties as institutional violence provoked by the health service, according to the speech below:

[...] we feel very bad, an anguish, because the need to be met is great, often you take "no" all your life, sometimes there is no doctor, no exam. Even the ultrasound that is not too expensive has... I was two weeks trying to schedule the appointment here, I only got it because I came straight here [reference], and booked the first week, but by the health center had no vacancy, and when it can sometimes it's far. (PW1)

[...] no, there is no violence here, the problem here is the lack of medicine, tests, appointments, there is never anything, everything is very difficult, because sometimes a medicine like ferrous sulfate, which is very cheap, very sad, very neglectful... (PW2)

[...] I didn't even get ferrous sulfate ... there is a doctor and a nurse to take care of a horror of people... then when it is not served, doctors scoff... I think that's wrong, because they are not to blame, I didn't say anything, I don't mess up, I stay out of it. (PW4)
Through the participants' speeches, it is noticed the presence of anguish, worry and sadness, due to the difficulties experienced in high-risk pregnancy. Some pregnant women related this difficulty to their financial condition, as they could resolve more quickly in the private health service. One of the pregnant women revealed that these difficulties lead to violence against the worker, although not explicitly revealed.

[...] we feel unsuccessful not being able to pay private appointment, I feel distressed, worried. Here only this week I will have two appointments, every time the doctor asks for an ultrasound, I mark, but there [Primary Care/FHS] we cannot. The doctor and thenurse of the health center do their work, but there is nothing, there is no vacancy, there is much difficulty. (PW6)

[...] I think the professionals are not to blame because they are working. There are people who cannot get the appointment, the exam, "mess up" and blame the professional. The fault is the management that does not put the medicines, doctor, nurse to serve. (PW8)

\section{DISCUSSION}

Institutional violence is hidden, silent and silenced in the care networks of the city of Fortaleza, as it is not guaranteed the comprehensiveness of care, the presence of violation of the rights of high-risk pregnant women in the access of PC to SC.

In prenatal care in the city surveyed, the initial appointment is performed by a nurse, with appointments interspersed with the doctor, following the protocol of Fortaleza's Ministry of Health and Municipal Health Office (MHO). Thus, the access of pregnant women to high-risk prenatal care occurs after risk stratification in the FHS. It is divided into three risks, according to the clinical guidelines for pregnant women care for MHO: usual risk, intermediate risk and high risk. In the latter situation, the pregnant woman is referred to a referral service for specialized follow-up, either in secondary and/or tertiary care after evaluation and appointment of the appointment by the city's central regulator.

Access to health services is a complex issue, involving different aspects such as political, economic, social, organizational, technical and symbolic in establishing paths for universal care ${ }^{(16)}$. Another component of access refers to the characteristics of the services offered, which favor or not the use and validation of the user, regarding the ability to meet their health needs ${ }^{(17)}$.

It is noticed that the public services of the country still cannot meet the needs of the population, in accordance with the legislation. There is a (lack of) accountability of the State as to the guarantee of the right to population's health, especially that of women in high-risk pregnancy, as it has experienced different difficulties, even being in this condition.

Despite the fact that PC through the FHS is considered the preferential gateway for the health system in Fortaleza, it was noted the deficiency in guaranteeing comprehensive care for women in high-risk pregnancy in both care networks, especially with regard to access to the SC. Corroborates with other national studies of local scope that show the existence of failures in prenatal care, such as difficulties in access, late start, inadequate number of appointments and incomplete procedures, affecting its quality and effectiveness ${ }^{(18-19)}$. 
From this difficulty, it is possible to infer the concept of structural violence present in health services, such as the form of organization of the work process, the deficiency of human and material resources, the non-regionalization of specialized appointments, the difficulty present during high-risk newborn child revealed by respondents leading to institutional violence.

The study revealed the lack of an institutionalized flow that ensures the pregnant woman's walk in the care networks safely, as well as the lack of dialogue between the networks. This noncommunication may contribute to the non-return of many highrisk pregnant women for PC after follow-up in SC. Therefore, even pregnant women who are in high risk condition are responsible for the PC/FHS team, their follow-up should happen, whether through care at the $\mathrm{BHU}$, home visits and others. Thus, the structuring of an efficient referral and counter-referral system demands effective actions that counterbalance the effects of distancing and different perspectives of care ${ }^{(17)}$.

The lack of integration of the healthcare network, associated with insufficient supply, has a negative impact on access to specialized services, considered the major bottleneck of SUS ${ }^{(20)}$. In this sense, it is clear that even in a system guided by the principles of territorialization and coordination of actions, for several decades, the integration between Primary Health Care (PHC) and specialized care is still fragile. They operate with separate management structures, which shows difficulties in changing cultures and interests ${ }^{(21)}$.

Care networks integration in high-risk prenatal care is fundamental based on the effective and institutionalized referral and counter-referral implementation. This occurs through the regional appointment regulation center, as well as the monitoring of high-risk pregnant women referred to SC by PC through family health teams.

It was noticed, therefore, that despite the universal system in Brazil, the citizen, especially the high-risk pregnant woman, experiences difficulties in accessing the care networks, especially the SC, as they face a waiting line, regardless of their condition and gestational age. The non-recognition of the right to health is perceived when one of the interviewees refers to the difficulty of access due to not being able to perform the exam. However, at no time did he reveal that by not having access, his right was violated. Thus, the limited exercise of citizenship is also influenced by the population's limited perception of their rights ${ }^{(22)}$.

Important advances in the regulatory process occurred in the city, but were not sufficient to meet the needs of the population. Decentralization of regulation to regional health was one of the strategies implemented by the municipal management and has contributed to the monitoring and monitoring of the queue. However, the regionalization of SC is still a challenge, especially for high-risk prenatal care.

Therefore, despite the advances, it is still necessary to improve the flow, because they occur differently in regional health. In some cases the pregnant woman is referred to the regional for this access because they are not sure of this schedule, in fact, the guarantee is deficient. In Brazil, the long waiting times for appointments, specialized examinations are the major cause of dissatisfaction reported by users of the Brazilian Health System (SUS - Sistema Único de Saúde) ${ }^{(23)}$.
In this sense, regulation is a social production comprising different logics, rationalities and proceduralities. Therefore, this situation consists in an always tense and provisional result of the crossing of the organizational multiplicity of the health system ${ }^{(16)}$.

These situations present in high-risk pregnancy contribute to the presence of institutional violence, although it is invisible, especially during prenatal care. Different studies were conducted on institutional violence in pregnancy, however, they were directed to obstetric violence at birth ${ }^{(24-26)}$. Thus, the institutional violence experienced by high-risk pregnant women when they remain in a waiting line for specialized care, for example, is naturalized.

Therefore, institutional violence is present in the different care networks, it is configured in the action or omission and in the abusive power of the State when it does not guarantee adequate attention. However, there is a deficiency in the understanding of some of the interviewees about this form of violence. Therefore, we hope to provoke reflections on the presence of present institutional prenatal violence, especially the high-risk ones.

Faced with several evidenced aspects about the institutional violence present in high-risk pregnancy, the study led to a series of questions about the difficulties experienced by high-risk pregnant women, which is totally dependent on government action. An important issue to consider is whether this idea of risk assumed in a work process by the city has been able to produce life-enhancing actions. If daily life is not observed, "Make to die and let live".

Thus, this type of violence is imposed, veiled, subtle, and occurs in a relationship of subordination, submission and domination, and is not recognized as such in health services, high-risk pregnant women and health professionals.

This issue was observed in the nurses' speeches because although many of the interviewees understand institutional violence as the lack of access to health services in different dimensions, few of them related to the right to health guaranteed by the FC. This right, based on aspects such as citizenship, dignity and popular sovereignty. Health is now declared as a fundamental right of citizenship, and the State has the obligation to provide it to all citizens ${ }^{(27)}$. Thus, discussions about the problem are necessary, so that in fact this theme has greater visibility in different spaces for greater coping of the problem.

Nurses and pregnant women used different means in search of specialized care. Going to the queue does not guarantee this attention, a situation revealed by nurses and high-risk pregnant women. Thus, different movements perform, among them, the search for the friend SUS. A survey conducted in two large cities in the region of $A B C D$ (The $A B C D$ includes the municipalities of Santo André, São Bernardo do Campo, São Caetano do Sul, Diadema, Mauá, Ribeirão Pires and Rio Grande da Serra), in the state of São Paulo, to characterize other existing logic of regulation corroborates the findings of this research, besides the governmental one, also referred to clientelistic regulation, professional regulation, and performed by users ${ }^{(28)}$. Therefore, it is clear that referral to SC brings uncertainties not only for pregnant women, but also for health professionals, since what is not always established is effective.

The understanding of pregnant women interviewed about this form of violence is still very limited to other forms of violence, 
as they do not relate to the violation of rights, although they perceive different situations that constitute violence, but it is not clear to them.

Failure to recognize the violation of the law as violence makes it difficult to visualize the problem and the effective action of the state regarding the guarantee of the law. In revisiting the proposals of the Women's Municipal Conference (Conferência Municipal da Mulher) held in 2017 in Fortaleza, none of them are related to this form of violence during prenatal care.

The lack of discussion about this form of violence in health services, training and/or other spaces contributes to the invisibility of the problem. So the words of Bourdieu \& Passeron are remembered stating that ${ }^{(10)}$ "the public problem is a problem that deserves to be dealt with publicly, officially". Therefore, not giving visibility to the problem contributes to its naturalization.

Institutional violence is little discussed, even when the violation of pregnant women's rights is perceived, especially the high-risk, few have been outraged by the situation, only silenced, not perceiving them as a subject of law. Therefore, in this form of violence, there is also the presence of structural violence that occurs by social inequality and is naturalized in the manifestations of poverty, misery and discrimination ${ }^{(11)}$.

Despite the Stork Network (Rede Cegonha) implementation by the federal government, the advances made in the city of the study were not sufficient to ensure comprehensive care for women during pregnancy. Much of what is guided remains in the instance of ideas, structured in the decrees, ordinances and policies implemented by governmental bodies.

Therefore, it is essential that the organization of the motherchild network actually takes place, from the guarantee of access in the different dimensions. Under no circumstances should pregnant women, especially those at high risk, return to health services for care and / or stand in line for any services needed for their care. The situation is even more complex in Fortaleza, as there is a deficiency in population coverage by the FHS/CHA, and makes it difficult to monitor the high-risk pregnant women referred from the PC to specialized care.

From the speeches of pregnant women and nurses, it was realized that the presence of these difficulties can contribute to complications not only for women in pregnancy, but also for the newborn. This is a worrying situation given the scenario of increased infant mortality in the city studied over the last three years.

Violation of human rights is represented as a violence that has no visibility, there is a deficiency in studies that articulate this form of violence from the violation of rights, especially in high-risk pregnancies. Another important issue is the lack of instituting movements of health professionals and the population, especially women in this condition, since non-access has often generated conformity, trivialization.

Violence in obstetric care is perceived through the symbolic power suffered by women, carried out by pressure and accepted through the recognition and obedience of what is put in health services. It is noticed that this is the most favorable way of the occurrence of this violence and often end up disguising the actual unequal intentions and power relations in force, turning them into acceptable, forming a relationship between dominant and dominated ${ }^{(10)}$.
Recognizing the presence of symbolic violence through emancipatory force, through the knowledge and recognition of its existence in the care networks that serve high-risk pregnant women, becomes necessary. Therefore, seeking patterns of organization, not domination to promote a life with dignity for pregnant women and children is also of paramount importance.

Thus, the high-risk pregnant woman has experienced victimization, victimization and revictimization through these situations, often constituting a negligence and (lack of) accountability, especially of those who should protect iy, the State.

\section{Study limitations}

It is considered as limit of this research the accomplishment in only one BHU per regional. Thus, it does not allow the generalization of the findings. However, the results indicate the need for improvements in the health services of the city studied to cope with the borderline situations experienced by high-risk pregnant women, among them, ensuring access in their different dimensions, as well as other studies that address this theme.

\section{Contributions to nursing, health or public policy}

The discussion and reflection on institutional violence may support social movements, women's movements, managers and health professionals, especially nursing professionals, regarding the limiting situations present in health services that lead to this form of violence. Non-naturalization and indignation are required. Therefore, the inclusion of this theme in the training of nurses and other health professionals is necessary, as well as in health education actions aimed at the community, especially for pregnant women, leading to reflections on human rights, legislation, as well as greater empowerment of their rights.

\section{FINAL CONSIDERATIONS}

Institutional violence is present in the care of high-risk pregnant women in the city studied, because their rights are violated when full attention is not guaranteed, access to their different needs, as was perceived from the interviewees' reports.

It was noticed that this form of violence is hidden, naturalized and often not perceived by high-risk nurses and pregnant women as institutional violence, even though explicitly mentioning the presence of violation of rights.

Therefore, it is essential that pregnant women, especially high-risk women, nurses and other health professionals reflect and discuss this issue for greater empowerment of women in pregnancy, especially those at high risk, in order to better understand what the right to health is guaranteed in the Federal Constitution.

Thus, this study sought to give visibility on the borderline situations faced by high-risk pregnant women regarding the access of PC to SC. Points out the need for improvement in the organization of the work process, integration of the PC and SC networks, based on permanent dialogue in order to ensure comprehensive attention. Therefore, serving a high-risk pregnant woman is responsible for the two care networks, requiring shared care. 
Nurses presented different perceptions about this form of violence, for some it is an unknown form of violence, except at the time of childbirth, however for others this form of violence is the violation of the rights of the high-risk pregnant woman.

The pregnant women, despite reporting difficulties regarding access to health care, had difficulties in understanding that they actually experience institutional violence. This is due to the state not guaranteeing to meet its needs, often undergoing a process of conformism and alienation. It was noticed in the study the existence of instituting movements to face the difficulties experienced by the interviewees, however they are still insufficient in view of the complexity of the problem.
Finally, considering that it is a topic of great social magnitude, little understood and recognized by high-risk pregnant women and nurses, it is necessary to cope with the phenomenon. Effective actions should be taken, such as integrating the PC and SC networks, ensuring access to quality PC prenatal care to the SC, medications and exams in a timely manner, regionalization of specialized care, referral and counter-referral, and their inclusion in community health education and training processes. Greater phenomenon coping through women's empowerment regarding their rights and continuing education for all health professionals stands out. Finally, we suggest further studies related to the path of high-risk pregnant women in both care networks.

\section{REFERENCES}

1. Ministério da Saúde (BR). Gestação de alto risco: manual técnico [Internet]. 5. ed. 20122013 [cited 2016 Aug 11]. Available from: http:// bvsms.saude.gov.br/bvs/manual_tecnico_gestacao_alto_risco.pdf

2. Ricci SS. Enfermagem materno-neonatal e saúde da mulher. Rio de Janeiro: Guanabara Koogan, 2015.

3. Rodrigues AR, Dantas SLC, Pereira AMM, Silveira MAM, Rodrigues DP. Gravidez de Alto Risco: Análise dos Determinantes de Saúde. SANARE [Internet] 2017[cited 2016 Aug 11];16(Supl-01):23-28-7. Available from: https://sanare.emnuvens.com.br/sanare/article/view/1135

4. Wildschut HIJ. Constitutional and environmental factors leading to a high risk pregnancy. In: James DK, Weiner CP, Gonik B, Crowther CA, Robson SC, (Eds.). High Risk Pregnancy: Management Options. Amsterdã: Elsevier; 2011. p.11-28.

5. Ministério da Saúde (BR). Portaria no 1.020, de 29 de maio de 2013. Institui as diretrizes para a organização da Atenção à Saúde na Gestação de Alto Risco e define os critérios para a implantação e habilitação dos serviços de referência à Atenção à Saúde na Gestação de Alto Risco, incluída a Casa de Gestante, Bebê e Puérpera (CGBP), em conformidade com a Rede Cegonha [Internet]. 2013 [cited 2016 Aug 11]. http:// bvsms.saude.gov.br/bvs/saudelegis/gm/2013/prt1020_29_05_2013.html

6. Pedrosa CM, Spink MJP. A violência contra a mulher no cotidiano dos serviços de saúde: desafios para a formação médica. Saúde Soc. 2011;20(1):124-35. doi: 10.1590/S0104-12902011000100015

7. Ladeia PSS, Mourão TT, Melo EM. O silencio da violência institucional no Brasil. Rev Med Minas Gerais [Internet]. 2016[cited 2016 Aug 11];26(Supl-8):S398-S401. Available from: http://rmmg.org/artigo/detalhes/2186

8. Assis MMA, Jesus WLA. Acesso aos serviços de saúde: abordagens, conceitos, políticas e modelo de análise. Ciênc Saúde Coletiva. 2012;17(11):2865-75. doi: 10.1590/S1413-81232012001100002

9. Giovanella L, Fleury S. Universalidade da Atenção à Saúde: acesso como categoria de análise. In: Eibenschutz C, (Org.). Política de Saúde: o público e o privado. Rio de Janeiro: Fiocruz; 1995. p. 177-98.

10. Bourdieu P. O poder simbólico. 16. ed. Rio de Janeiro: Bertrand Brasil, 2012. 322 p.

11. Minayo MCS. A Violência Social sob a Perspectiva da Saúde. Cad Saúde Públ [Internet]. 1994[cited 2016 Aug 11];10(supl-1):07-18. Available from: http://www.scielo.br/pdf/csp/v10s1/v10supl1a02.pdf

12. Bourdieu P, Passeron JC. A reprodução: elementos para uma teoria do sistema de ensino. Trad. Reynaldo Bairão. Petrópolis, RJ: Vozes, 2008.

13. Bourdieu P. A dominação masculina/Pierre Bourdieu: tradução Maria Helena Kühner. 11 ed. Rio de Janeiro: Bertrand Brasil; 2012. 160p.

14. Minayo MCS. Pesquisa social: teoria método e criatividade. Petrópolis RJ: Vozes; 2016.

15. Minayo MCS. O desafio do conhecimento: pesquisa qualitativa em saúde. 14. ed. São Paulo: Editora Hucitec; 2015.

16. Santos L, Andrade LOM. Acesso às ações e aos serviços de saúde: uma visão polissêmica. Ciênc Saúde Coletiva [Internet]. 2012 [cited 2016 Aug 11];17(11):2876-8. Available from: http://www.scielo.br/pdf/csc/v17n11/v17n11a03.pdf

17. Errico LSP, Bicalho PG, Oliveira TCFL, Martins EF. The work of nurses in high-risk prenatal care from the perspective of basic human needs. Rev Bras Enferm. 2018;71(Suppl 3):1257-64. [Thematic Issue: Health of woman and child]. doi: 10.1590/0034-7167-2017-0328

18. Coutinho T, Monteiro MFG, Sayd JD, Teixeira MTB, Coutinho CM, Coutinho LM. Monitoramento do processo de assistência pré-natal entre as usuárias do Sistema Único de Saúde em município do Sudeste brasileiro. Rev Bras Ginecol Obstet [Internet]. 2010[cited 2016 Aug 11];32:563-9. Available from: it http://www.scielo.br/pdf/rbgo/v32n11/v32n11a08.pdf

19. Domingues RMSM, Hartz ZMA, Dias MAB, Leal MC. Avaliação da adequação da assistência pré-natal na rede SUS do Município do Rio de Janeiro, Brasil. Cad Saúde Pública [Internet]. 2012[cited 2016 Aug 11];28:425-37. Available from: http://www.scielo.br/pdf/csp/v28n3/03.pdf

20. Almeida PF, Giovanella L, Mendonça MHM, Escorel S. Desafios à coordenação dos cuidados em saúde: estratégias de integração entre níveis assistenciais em grandes centros urbanos. Cad Saúde Pública. 2010;26(2):286-98. doi: 10.1590/\$0102-311×20100008 
21. Giovanella L, Mendonça MHM, Almeida PF, Escorel S, Senna MCM, Fausto MCR, et al. Saúde da família: limites e possibilidades para uma abordagem integral à saúde no Brasil. Ciênc Saúde Coletiva [Internet]. 2009[cited 2016 Aug 11];14(3):783-94. Available from: http://www. scielo.br/pdf/csc/v16n6/17.pdf

22. Silva RMS, Costa SC, Matsue RY, Sousa GS, Catrib, AMF, Vieira LJE. Cartografia do cuidado na saúde da gestante. Ciênc Saúde Coletiva [Internet]. 2012[cited 2016 Aug 11];17(3):635-42. Available from: http://www.scielo.br/pdf/csc/v17n3/v17n3a09.pdf

23. Conill EM, Giovanella L, Almeida PF. Listas de espera em sistemas públicos: da expansão da oferta para um acesso oportuno? considerações a partir do Sistema Nacional de Saúde espanhol. Ciênc Saúde Coletiva [Internet]. 2011[cited 2016 Aug 11];16(6):2783-94. Available from: http://www.scielo.br/pdf/csc/v16n6/17.pdf

24. Sena LM, Tesser CD. Violência obstétrica no Brasil e o ciberativismo de mulheres mães: relato de duas experiências. Interface. Comun Saúde Educ [Internet]. 2017[cited 2016 Aug 11];21(60):209-20. Available from: http://www.redalyc.org/pdf/1801/180148881019.pdf

25. Rodrigues DP, Alves VH, Penna LHG, Pereira AV, Branco MBLR, Silva LA. The pilgrimage in reproductive period: a violence in the field of obstetrics. Esc Anna Nery [Internet]. 2015[cited 2016 Aug 11];19(4):614-20. Available from:http://www.scielo.br/pdf/ean/v19n4/en_14148145-ean-19-04-0614.pdf

26. Aguiar JM, D'Oliveira AFPL. Violência institucional em maternidades públicas sob a ótica das usuárias. Interface - Comunic Saúde Educ [Internet]. 2011 [cited 2016 Aug 11];15(36):79-91. http://www.redalyc.org/articulo.oa?id=180119115004

27. Cecílio LCO. Colegiados de gestão em serviços de saúde: um estudo empírico. Cad Saúde Pública. 2010[cited 2016 Aug 11];26(3):557-66. Available from: http://www.scielo.br/pdf/csp/v26n3/13.pdf

28. Cecilio LCO, Spedo SM. O agir leigo e o cuidado em saúde: a produção de mapas de cuidado. Cad. Saúde Pública. 2014[cited 2016 Aug 11];30(7):1502-14. https://www.scielosp.org/articlr/csp/2014 